\title{
Mortality Risk and Temporal Patterns of Atrial Fibrillation in the Nationwide
}

\section{Registry}

\section{Apiyasawat}

Short Title: Mortality Risk in Non-paroxysmal AF

Sirin Apiyasawat, $\mathrm{MD}^{1}$; Sakaorat Kornbongkotmas, $\mathrm{MD}^{2}$; Ply Chichareon, $\mathrm{MD}^{3}$; Rungroj

Krittayaphong, $\mathrm{MD}^{4}$; for the COOL-AF Investigators

Links to Affiliations:

${ }^{1}$ Faculty of Medicine Ramathibodi Hospital, Mahidol University, Bangkok, Thailand

${ }^{2}$ Queen Savang Vadhana Memorial Hospital, Chonburi, Thailand

${ }^{3}$ Faculty of Medicine, Prince of Songkla University, Songkla, Thailand

${ }^{4}$ Faculty of Medicine, Siriraj Hospital, Mahidol University, Bangkok, Thailand

Address for correspondence:

Rungroj Krittayaphong, MD

Division of Cardiology, Department of Medicine, Faculty of Medicine Siriraj Hospital, Mahidol University, Bangkok, Thailand

Phone: (66) 2-419-6104; Fax: (66) 2-412-7412, E-mail: rungroj.kri@ mahidol.ac.th

Word Count: 2299 


\title{
Mortality Risk and Temporal Patterns of Atrial Fibrillation in the Nationwide
}

\section{Registry}

\author{
Abstract \\ Aims \\ Persistent and permanent atrial fibrillation (AF) often occurs in the presence of multiple \\ comorbidities and is linked to adverse clinical outcomes. It is unclear whether the sustained \\ pattern of AF itself is prognostic or if it is confounded by underlying comorbidities. Here, we \\ tested the association between the temporal patterns of AF and the risks of ischemic stroke and \\ all-cause mortality.
}

\section{Methods and Results}

In a prospective multicenter cohort, 3046 non-valvular AF patients were consecutively enrolled and followed for adverse outcomes of all-cause mortality and ischemic stroke. The risks of both outcomes were adjusted for underlying comorbidities, and compared between the patterns of AF. At baseline, the patients were classified as paroxysmal $(\mathrm{N}=963,31.6 \%)$, persistent $(\mathrm{N}=604$, $19.8 \%)$, and permanent $\mathrm{AF}(\mathrm{N}=1479,45.6 \%)$ according to the standard definition.

Anticoagulants were administered in $75 \%$ of all patients and $83 \%$ of those with $\mathrm{CHA}_{2} \mathrm{DS}_{2}-\mathrm{VAS}_{\mathrm{c}}$ score $\geq 2$ in males or $\geq 3$ in females. During a mean follow up of 26 (SD 10.5) months, all-cause mortality occurred less in paroxysmal AF (2.5 per 100 patient-years) than in persistent AF (4.4 per 100 patient-years; adjusted hazard ratio [HR] 0.66, 95\% CI, 0.46-0.96; $P=.029$ ) and permanent AF (4.1 per 100 patient-years; adjusted HR 0.71, 95\% CI, 0.52-0.98; $P=.036)$. The risk of ischemic stroke was similar across all patterns of AF. 
medRxiv preprint doi: https://doi.org/10.1101/2021.01.30.21250715; this version posted June 17, 2021. The copyright holder for this preprint (which was not certified by peer review) is the author/funder, who has granted medRxiv a license to display the preprint in perpetuity.

It is made available under a CC-BY-NC-ND 4.0 International license .

\section{Conclusions}

In this multicenter nationwide registry of AF patients, persistent and permanent $\mathrm{AF}$ was associated with higher all-cause mortality than paroxysmal AF, independent of baseline comorbidities.

\section{Clinical Trial Registration}

Thai Clinical Trial Registration; Study ID: TCTR20160113002

\section{Keywords}

atrial fibrillation, atrial fibrillation type, mortality, stroke, registry

Word Count: 2299 
medRxiv preprint doi: https://doi.org/10.1101/2021.01.30.21250715; this version posted June 17, 2021. The copyright holder for this preprint (which was not certified by peer review) is the author/funder, who has granted medRxiv a license to display the preprint in perpetuity.

It is made available under a CC-BY-NC-ND 4.0 International license .

\section{Introduction}

Atrial fibrillation (AF) is categorized into paroxysmal, persistent, and permanent according to temporal patterns. Studies have been shown that approximately one-third ${ }^{1}$ to one-fourth ${ }^{2}$ of patients with paroxysmal AF progress to persistent AF within 10 years. This ratio is even higher in the presence of structural heart disease_-reportedly more than half progressing in 10 years. ${ }^{3}$ Those with persistent forms of AF are linked to higher comorbidities and worse clinical outcomes. $^{2,4-7}$

Current recommendation for management of AF focuses on controlling comorbidities to reduce adverse events rather than interrupting the progression of $\mathrm{AF}{ }^{8}$ However, recent trials suggested that the temporal pattern of AF itself may be an independent predictor of clinical outcomes. ${ }^{4,9}$ Persistent form of AF can lead to both atrial and ventricular remodeling that could subsequently progress to AF-mediated cardiomyopathy. ${ }^{10-12}$ Interrupting the progression of AF at the early stage has also recently been shown to reduce stroke and cardiovascular death. ${ }^{13}$

Here, we aim to investigate the association between the temporal patterns of AF and adverse clinical outcomes in the COOL-AF registry (은

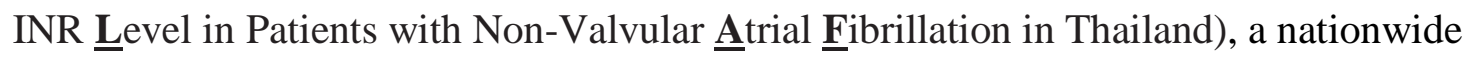
prospective cohort of AF patients. We hypothesize that paroxysmal AF was associated with lower mortality and stroke risks than persistent or permanent AF. 
medRxiv preprint doi: https://doi.org/10.1101/2021.01.30.21250715; this version posted June 17, 2021. The copyright holder for this preprint (which was not certified by peer review) is the author/funder, who has granted medRxiv a license to display the preprint in perpetuity.

It is made available under a CC-BY-NC-ND 4.0 International license .

\section{Methods}

\section{Study Population}

COOL-AF registry is a multicenter prospective cohort study of patients with AF patients without significant valvular diseases. The study consecutively enrolled patients from 27 hospitals ${ }^{14}$ across all regions of Thailand. The inclusion and exclusion criteria were described previously. ${ }^{14}$ Briefly, adults (ie, age >18) with electrocardiography-confirmed AF were eligible for the enrolment. The exclusion criteria were (1) ischemic stroke within 3 months; (2) hematologic disorders that can increase the risk of bleeding such as thrombocytopenia $\left(<100000 / \mathrm{mm}^{3}\right)$ and myeloproliferative disorders; (3) mechanical prosthetic valve or valve repair; (4) rheumatic valve disease or severe valve disease; (5) AF associated with transient reversible cause; (6) current participation in a clinical trial; (7) life expectancy <3 years; (8) pregnancy; (9) inability to attend follow-up visits; and (10) refusal to participate in the study. The protocol was approved by the ethics committee of each participating hospital. All patients provided written informed consent.

\section{Data Collection}

The source of data were medical records and patients or family interviews. Data collected at baseline included demographic profile, body weight and height, temporal pattern of AF, medical history, clinical examination, laboratory data, medication use, and all components $\mathrm{CHA}_{2} \mathrm{DS}_{2}{ }^{-}$ $\mathrm{VAS}_{\mathrm{c}}$ and HASBLED scores. All patients were prospectively followed every 6 months for a total of 36 months. Those with newly diagnosed AF and those with incomplete data were excluded from this analysis. Data collected during follow up included medical history, clinical outcomes, medications, and laboratory data.

The enrolment and all data acquisition occurred between 2014 - 2017. All data were entered in a predefined web-based form and centrally validated for completion. Monitoring visits 
medRxiv preprint doi: https://doi.org/10.1101/2021.01.30.21250715; this version posted June 17, 2021. The copyright holder for this preprint (which was not certified by peer review) is the author/funder, who has granted medRxiv a license to display the preprint in perpetuity.

It is made available under a CC-BY-NC-ND 4.0 International license .

were conducted at all participating sites to ensure compliance with the protocol and validity of the data.

\section{Definitions}

Temporal patterns of AF were classified by investigators as paroxysmal (AF that terminates spontaneously or with intervention within 7 days of onset), persistent (AF that is continuously sustained beyond 7 days), and permanent (AF that is accepted by the patient and physician, and no further attempts to restore/maintain sinus rhythm will be undertaken.) according to the standard guideline. ${ }^{8,15}$ Congestive heart failure (CHF), coronary artery disease (CAD), and vascular disease were defined using the same criteria of those used in $\mathrm{CHA}_{2} \mathrm{DS}_{2}-\mathrm{VAS}_{\mathrm{c}}$ score. ${ }^{8,15}$ Briefly, $\mathrm{CHF}$ was described as clinical heart failure, or objective evidence of moderate to severe left ventricular dysfunction, or hypertrophic cardiomyopathy, CAD as angiographically significant coronary artery disease or previous myocardial infarction, and vascular disease as the presence of $\mathrm{CAD}$, peripheral artery disease, or presence of aortic plaque. Presence of dialysis, transplant, serum creatinine $>200 \mu \mathrm{mol} / \mathrm{L}$ was classified as abnormal renal function, and presence of cirrhosis, bilirubin $>\times 2$ upper limit of normal, AST/ALT/ALP $>3 \times$ upper limit of normal as abnormal liver function, according to the criteria used in HASBLED score. ${ }^{8,15}$ Risk of ischemic stroke was assessed by $\mathrm{CHA}_{2} \mathrm{DS}_{2}-\mathrm{VAS}_{\mathrm{c}}$ score and further classified as low $\left(\mathrm{CHA}_{2} \mathrm{DS}_{2}\right.$ $\mathrm{VAS}_{\mathrm{c}}$ score $=0$ in males, or 1 in females $)$, intermediate $\left(\mathrm{CHA}_{2} \mathrm{DS}_{2}-\mathrm{VAS}_{\mathrm{c}}\right.$ score of 1 in males or 2 in females), and high $\left(\mathrm{CHA}_{2} \mathrm{DS}_{2}-\mathrm{VAS}_{\mathrm{c}}\right.$ score $\geq 2$ in males or $\geq 3$ in females), as recommended by the standard guideline. ${ }^{8}$

\section{Assessment of Clinical Outcomes}

Patients were prospectively followed for the primary outcomes of all-cause mortality and ischemic stroke. The secondary outcomes were cardiovascular death, major bleeding, and 
medRxiv preprint doi: https://doi.org/10.1101/2021.01.30.21250715; this version posted June 17, 2021. The copyright holder for this preprint (which was not certified by peer review) is the author/funder, who has granted medRxiv a license to display the preprint in perpetuity.

It is made available under a CC-BY-NC-ND 4.0 International license .

intracranial hemorrhage. The occurrence of these events was monitored every 6 months until the end of follow-up at 36 months. All events were validated by the adjudication committee.

Ischemic stroke was defined as an episode of neurological dysfunction caused by focal cerebral, spinal, or retinal infarction. ${ }^{16}$ Major bleeding was defined according to the International Society of Thrombosis and Haemostasis criteria, ${ }^{17}$ which were fatal bleeding, bleeding in a critical area or organ(s), bleeding that results in a decrease in hemoglobin level of at least $20 \mathrm{~g} / \mathrm{L}$, and bleeding that requires a transfusion of at least two units of red cells.

\section{Statistical Analysis}

Continuous data were reported as mean (SD); categorical data, as number (percentage). The event rates of the clinical outcomes were measured as patient-year. Differences in baseline characteristics between the patterns of AF were compared by using One-way ANOVA with posthoc least significant difference test for continuous variables and Chi-square test with post-hoc pairwise comparisons for categorical variables. Kaplan-Meier with log-rank test was used to estimate the survival differences between the patterns. Hazard ratios (HRs) with $95 \%$ confidence intervals $(\mathrm{CI})$ of clinical outcomes were calculated by Cox proportional hazards models. Using backward step-wise selection method, the models were adjusted with age, sex, body mass index, smoking status, alcohol use, hypertension, dyslipidemia, bleeding history, CHF, diabetes mellitus, history of stroke or transient ischemic attack (Stroke/TIA), vascular disease, abnormal renal function, abnormal liver function, use of antiplatelet, and use of anticoagulant. Validation for proportional hazards assumption was performed using Schoenfeld tests for all global models and scaled Schoenfeld residuals for each covariate. ${ }^{18}$ There were no violations detected graphically or by Grambsch-Therneau tests (ie, all $P$ values for global models and for each covariate were $>.05)$. Statistical adjustment for multiplicity was not performed due to the 
medRxiv preprint doi: https://doi.org/10.1101/2021.01.30.21250715; this version posted June 17, 2021. The copyright holder for this preprint (which was not certified by peer review) is the author/funder, who has granted medRxiv a license to display the preprint in perpetuity.

It is made available under a CC-BY-NC-ND 4.0 International license .

exploratory nature of this trial. ${ }^{19}$ A $P$ value of $<.05$ was considered significant. All analyses were conducted using IBM SPSS Statistics for Windows, Version 25.0 (Armonk, NY: IBM Corp.) and Stata Statistical Software: Release 13 (College Station, TX: StataCorp LP).

\section{Results}

\section{Baseline Findings}

A total of 3402 patients were enrolled in the COOL-AF registry. After excluding the patients with newly diagnosed $\mathrm{AF}(\mathrm{N}=91)$ and those with incomplete data $(\mathrm{N}=275), 3046$ patients (mean age 67.1, 41\% female, mean $\mathrm{CHA}_{2} \mathrm{DS}_{2}-\mathrm{VAS}_{\mathrm{c}}$ score 2.97) remained in the analysis. Of those, 963 patients (31.6\%) were classified as paroxysmal AF, 604 patients $(19.8 \%)$ as persistent $\mathrm{AF}$, and 1479 patients $(48.6 \%)$ as permanent AF (Table 1). Patients with paroxysmal AF were more likely female, less likely to have history of CHF, and had lower $\mathrm{CHA}_{2} \mathrm{DS}_{2}-\mathrm{VAS}_{\mathrm{c}}$ and HASBLED scores than those with persistent and permanent AF. The mean age of those with paroxysmal (65.9 years) and persistent (66.8 years) AF were relatively similar ( $P=.105$ between paroxysmal and persistent), but younger than those with permanent AF (mean age 68.1, $P<.001$ vs paroxysmal and $=.019$ vs persistent $)$. Risk of ischemic stroke was classified as high $\left(\mathrm{CHA}_{2} \mathrm{DS}_{2}-\right.$ $\mathrm{VAS}_{\mathrm{c}}$ score $\geq 2$ in males or $\geq 3$ in females) in 2239 patients $(73.5 \%)$. The overall anticoagulation rate in this group (Figure 1) was $82.6 \%(\mathrm{~N}=1849)$, highest in permanent $\mathrm{AF}(\mathrm{N}=985,86.0 \%)$, followed by persistent $(\mathrm{N}=349,79.3 \%, P$ vs permanent $<.001)$ and paroxysmal $(\mathrm{N}=515,78.9 \%$, $P$ vs permanent $=.001)$. Of all anticoagulants prescribed $(\mathrm{N}=2286)$, vitamin $\mathrm{K}$ antagonist $(\mathrm{VKA})$ was the most frequently used $(\mathrm{N}=2103,92 \%)$.

\section{Outcomes}

During a mean follow up of 26 (SD 10.5) months, 240 patients died (7.9\%; 3.6 per 100 patientyears). The causes of death (Table 2) were cardiovascular in 82 patients $(34.2 \%)$, non- 
medRxiv preprint doi: https://doi.org/10.1101/2021.01.30.21250715; this version posted June 17, 2021. The copyright holder for this preprint (which was not certified by peer review) is the author/funder, who has granted medRxiv a license to display the preprint in perpetuity.

It is made available under a CC-BY-NC-ND 4.0 International license .

cardiovascular in 110 patients (45.8\%), and undetermined in 48 patients (20\%). Those with paroxysmal AF were less likely to die of any causes (2.5 per 100 patient-years) than those with persistent AF (4.4 per 100 patient-years; adjusted HR 0.66, 95\% CI, 0.46-0.96; $P=.029$ ) and those with permanent AF (4.1 per 100 patient-years; adjusted HR 0.71, 95\% CI, 0.52-0.98; $P=$ .036; Figure 2 and Table 3). There were no differences in the incidence rates of cardiovascular death, non-cardiovascular death, ischemic stroke (Figure 3), and intracranial hemorrhage between the patterns of AF (Table 3). Major bleeding was fewer in patients with paroxysmal AF (1.5 per 100 patient-years) than those with persistent AF (2.6 per 100 patient-years; adjusted HR 0.59, 95\% CI, 0.67-0.97; $P=.037$; Table 3). Comparing between persistent and permanent AF, the incidences of all-cause mortality, cardiovascular death, ischemic stroke, and intracranial hemorrhage were not statistically different.

\section{Discussion}

In this prospective, multicenter cohort of AF patients, excess mortality risks were demonstrated in persistent and permanent AF over paroxysmal AF. The increase in mortality risk was independent of age, sex, use of anticoagulant, history of bleeding, and multiple comorbidities. The risks of ischemic stroke, on the other hand, were statistically similar across all patterns of $\mathrm{AF}$.

The prognostic significance of AF pattern has been analyzed in many trials and registries. Among selected, well-controlled, and well-anticoagulated population (ENGAGE AF-TIMI 48, ${ }^{5}$ ROCKET-AF, ${ }^{20}$ and AMADEUS ${ }^{21}$ trials), non-paroxysmal AF was independently associated with worse survival and higher thrombo-embolic event than paroxysmal AF. The results have been conflicting in "real-world" populations. In the Loire valley atrial fibrillation project, ${ }^{22}$ age and comorbidities, rather than pattern of $\mathrm{AF}$, were associated with risk of stroke and all-cause 
medRxiv preprint doi: https://doi.org/10.1101/2021.01.30.21250715; this version posted June 17, 2021. The copyright holder for this preprint (which was not certified by peer review) is the author/funder, who has granted medRxiv a license to display the preprint in perpetuity.

It is made available under a CC-BY-NC-ND 4.0 International license .

mortality. In the Fushimi ${ }^{9}$ and GARFIELD-AF ${ }^{23}$ registries, the independent association between adverse clinical outcomes and AF pattern were demonstrated but with some dissimilarity. In anticoagulated patients, one registry ${ }^{9}$ showed a prognostic significance of AF pattern in ischemic stroke but not all-cause mortality while a different study showed the contrary. ${ }^{23}$

Besides geographic area, there were some similarity and dissimilarity between the abovementioned registries and ours. Similar in all of these registries, VKA was the main anticoagulant. Time in therapeutic range (TTR) in our population, reported elsewhere, ${ }^{24}$ was achieved in $53.6 \%$ of 2233 patients taking VKA. Though suboptimal, the number was in line with the TTR of $51.4 \%$ in GARFILED-AF. ${ }^{25}$ The anticoagulation rate, however, was different between our registry and others. In our trial, there were more patients received anticoagulants $(75 \%$ of all patients, $83 \%$ of patients with high stroke risk) than those in other registries (40\% in Loire valley registry, ${ }^{22} 53 \%$ in Fushimi registry, ${ }^{9}$ and $68 \%$ in GARFIELD-AF ${ }^{23}$ ). Lastly, the ratio of nonparoxysmal AF was higher in ours (68\%) than in the other registries (42\% in Loire valley registry $^{22}$ and $51 \%$ in GARFIELD-AF ${ }^{23}$ ).

Multiple differences in baseline characteristics were detected between the patterns of AF in our patients. Those with paroxysmal AF were younger and less likely to have history of CHF than those with non-paroxysmal AF. On the other hand, among patients at high-risk for ischemic stroke, those with non-paroxysmal AF were better anticoagulated than those with paroxysmal AF. The imbalances in baseline risk factors, however, were all adjusted in a well-validated regression model. The regression analysis revealed an approximately $30 \%$ increase in mortality risk of non-paroxysmal over paroxysmal AF. Among the non-paroxysmal patterns themselves (persistent and permanent AF), the risks were statistically similar. These result support the concept that non-paroxysmal pattern of AF was not just a term of duration and frequency- 
medRxiv preprint doi: https://doi.org/10.1101/2021.01.30.21250715; this version posted June 17, 2021. The copyright holder for this preprint (which was not certified by peer review) is the author/funder, who has granted medRxiv a license to display the preprint in perpetuity.

It is made available under a CC-BY-NC-ND 4.0 International license .

rather, it was a disease state — an advanced form associated with worse outcomes. ${ }^{26}$ Finally, the increase in mortality risk was not driven by any particular causes of death either cardiovascular or non-cardiovascular. As a matter of fact, non-cardiovascular death occurred more frequently than cardiovascular death suggesting that a more comprehensive approach in AF management is essential to improving outcomes in our patients.

\section{Strengths}

The study design was prospective and multicenter. Data collection was validated and adjudicated. The incidences of the major outcomes were comparable to those reported globally and regionally ${ }^{9,22,27-29}$ reflecting the quality of AF management and the adequacy of event reporting. Finally, unlike most of the clinical trials, ${ }^{30}$ the Cox-regression models in our trial were validated for proportional assumptions.

\section{Limitations}

Due to the nature of the registry, only the association, not the causation, could be demonstrated. Baseline characteristics were not balanced and the therapeutic strategy was not controlled between groups. Despite statistical adjustment, residual confounders remained. Similar to previous trials, AF pattern was defined clinically at physician discretion, which is known to be subject to misclassification error. ${ }^{5-6,9,22-23}$ Vitamin K antagonist was the main choice of anticoagulant. The use of DOAC was limited by the reimbursement policy. The follow-up time was relatively short and may have some effects on the prognosis of chronic disease like AF. Lastly, the cause of death was reported as "undetermined" in $20 \%$ of all deaths. However, the prognostic significance of any specific causes of death was not the primary research question here. 
medRxiv preprint doi: https://doi.org/10.1101/2021.01.30.21250715; this version posted June 17, 2021. The copyright holder for this preprint (which was not certified by peer review) is the author/funder, who has granted medRxiv a license to display the preprint in perpetuity.

It is made available under a CC-BY-NC-ND 4.0 International license.

\section{Conclusion}

In this multicenter cohort of AF patients without significant valvular diseases, the temporal pattern of AF was prognostic for all-cause mortality but not for ischemic stroke. Non-paroxysmal AF was associated with an approximately $30 \%$ increase in all-cause mortality. 
medRxiv preprint doi: https://doi.org/10.1101/2021.01.30.21250715; this version posted June 17, 2021. The copyright holder for this preprint (which was not certified by peer review) is the author/funder, who has granted medRxiv a license to display the preprint in perpetuity.

\section{It is made available under a CC-BY-NC-ND 4.0 International license .}

\section{Clinical Perspectives}

Competency in Patient Care

Non-paroxysmal atrial fibrillation was associated with increased risk of all-cause mortality based on the evidence from the real-world prospective registry of non-valvular AF patients. The association was independent of age, sex, comorbidities, and anticoagulation status.

\section{Translation Outlook}

Early intervention to slow down or prevent the progression of AF may improve the clinical outcomes pending the result from a larger randomized clinical trial. 
medRxiv preprint doi: https://doi.org/10.1101/2021.01.30.21250715; this version posted June 17, 2021. The copyright holder for this preprint (which was not certified by peer review) is the author/funder, who has granted medRxiv a license to display the preprint in perpetuity.

It is made available under a CC-BY-NC-ND 4.0 International license .

\section{References}

1. Padfield GJ, Steinberg C, Swampillai J, Qian H, Connolly SJ, Dorian P, et al.

Progression of paroxysmal to persistent atrial fibrillation: 10-year follow-up in the

Canadian Registry of Atrial Fibrillation. Heart Rhythm. 2017;14(6):801-7. Epub

2017/02/25. doi: 10.1016/j.hrthm.2017.01.038. PubMed PMID: 28232263.

2. Potpara TS, Stankovic GR, Beleslin BD, Polovina MM, Marinkovic JM, Ostojic MC,

Lip GYH. A 12-year follow-up study of patients with newly diagnosed lone atrial fibrillation: implications of arrhythmia progression on prognosis: the Belgrade Atrial Fibrillation study. Chest. 2012 Feb;141(2):339-347. doi: 10.1378/chest.11-0340. Epub 2011 May 26. PMID: 21622553.

3. Kato T, Yamashita T, Sagara K, Iinuma H, Fu LT. Progressive nature of paroxysmal atrial fibrillation. Observations from a 14-year follow-up study. Circ J.

2004;68(6):568-72. Epub 2004/06/01. doi: 10.1253/circj.68.568. PubMed PMID: 15170094.

4. Chiang C-E, Naditch-Brûlé L, Murin J, Goethals M, Inoue H, O’Neill J, et al. Distribution and risk profile of paroxysmal, persistent, and permanent atrial fibrillation in routine clinical practice. Circulation: Arrhythmia and Electrophysiology. 2012;5(4):632-9. doi: doi:10.1161/CIRCEP.112.970749.

5. Link MS, Giugliano RP, Ruff CT, Scirica BM, Huikuri H, Oto A, et al. stroke and mortality risk in patients with various patterns of atrial fibrillation: results From the ENGAGE AF-TIMI 48 trial (effective anticoagulation with factor xa next generation in atrial fibrillation-thrombolysis in myocardial infarction 48). Circ Arrhythm 
medRxiv preprint doi: https://doi.org/10.1101/2021.01.30.21250715; this version posted June 17, 2021. The copyright holder for this preprint (which was not certified by peer review) is the author/funder, who has granted medRxiv a license to display the preprint in perpetuity.

It is made available under a CC-BY-NC-ND 4.0 International license .

Electrophysiol. 2017;10(1). Epub 2017/01/13. doi: 10.1161/circep.116.004267.

PubMed PMID: 28077507.

6. Lubitz SA, Benjamin EJ, Ruskin JN, Fuster V, Ellinor PT. Challenges in the classification of atrial fibrillation. Nature Reviews Cardiology. 2010;7(8):451-60. doi: 10.1038/nrcardio.2010.86.

7. Kannel WB, Abbott RD, Savage DD, McNamara PM. Epidemiologic features of chronic atrial fibrillation. New England Journal of Medicine. 1982;306(17):1018-22. doi: 10.1056/NEJM198204293061703.

8. Hindricks G, Potpara T, Dagres N, Arbelo E, Bax JJ, Blomström-Lundqvist C, et al. 2020 ESC Guidelines for the diagnosis and management of atrial fibrillation developed in collaboration with the European Association of Cardio-Thoracic Surgery (EACTS). Eur Heart J. 2020. Epub 2020/08/30. doi:

10.1093/eurheartj/ehaa612. PubMed PMID: 32860505.

9. Takabayashi K, Hamatani Y, Yamashita Y, Takagi D, Unoki T, Ishii M, et al. Incidence of stroke or systemic embolism in paroxysmal versus sustained atrial fibrillation: the Fushimi Atrial Fibrillation Registry. Stroke. 2015;46(12):3354-61. Epub 2015/10/31. doi: 10.1161/strokeaha.115.010947. PubMed PMID: 26514188.

10. Kuppahally SS, Akoum N, Burgon NS, Badger TJ, Kholmovski EG, Vijayakumar S, et al. Left atrial strain and strain rate in patients with paroxysmal and persistent atrial fibrillation. Circulation: Cardiovascular Imaging. 2010;3(3):231-9. doi: doi:10.1161/CIRCIMAGING.109.865683. 
medRxiv preprint doi: https://doi.org/10.1101/2021.01.30.21250715; this version posted June 17, 2021. The copyright holder for this preprint (which was not certified by peer review) is the author/funder, who has granted medRxiv a license to display the preprint in perpetuity.

It is made available under a CC-BY-NC-ND 4.0 International license .

11. Shantsila E, Shantsila A, Blann AD, Lip GYH. left ventricular fibrosis in atrial fibrillation. The American Journal of Cardiology. 2013;111(7):996-1001. doi: https://doi.org/10.1016/j.amjcard.2012.12.005.

12. Qin D, Mansour MC, Ruskin JN, Heist EK. Atrial fibrillation-mediated cardiomyopathy. Circulation: Arrhythmia and Electrophysiology. 2019;12(12):e007809. doi: doi:10.1161/CIRCEP.119.007809.

13. Kirchhof P, Camm AJ, Goette A, Brandes A, Eckardt L, Elvan A, et al. Early rhythmcontrol therapy in patients with atrial fibrillation. New England Journal of Medicine. 2020;383(14):1305-16. doi: 10.1056/NEJMoa2019422.

14. Krittayaphong R, Winijkul A, Methavigul K, Wongtheptien W, Wongvipaporn C, Wisaratapong T, et al. Risk profiles and pattern of antithrombotic use in patients with non-valvular atrial fibrillation in Thailand: a multicenter study. BMC Cardiovasc Disord. 2018;18(1):174. Epub 2018/08/27. doi: 10.1186/s12872-018-0911-4. PubMed PMID: 30144802; PubMed Central PMCID: PMCPMC6109333.

15. January CT, Wann LS, Alpert JS, Calkins H, Cigarroa JE, Cleveland JC, et al. 2014 AHA/ACC/HRS guideline for the management of patients with atrial fibrillation: A Report of the American College of Cardiology/American Heart Association Task Force on Practice Guidelines and the Heart Rhythm Society. Journal of the American College of Cardiology. 2014;64(21):e1-e76. doi: https://doi.org/10.1016/j.jacc.2014.03.022

16. Sacco RL, Kasner SE, Broderick JP, Caplan LR, Connors JJ, Culebras A, et al. An Updated Definition of Stroke for the 21st Century. Stroke. 2013;44(7):2064-89. doi: doi:10.1161/STR.0b013e318296aeca. 
medRxiv preprint doi: https://doi.org/10.1101/2021.01.30.21250715; this version posted June 17, 2021. The copyright holder for this preprint (which was not certified by peer review) is the author/funder, who has granted medRxiv a license to display the preprint in perpetuity.

It is made available under a CC-BY-NC-ND 4.0 International license .

17. Schulman S, Kearon C, and (2005), Definition of major bleeding in clinical investigations of antihemostatic medicinal products in non $\square$ surgical patients. Journal of Thrombosis and Haemostasis, 3: 692-694. https://doi.org/10.1111/j.15387836.2005.01204.x.

18. Hickey GL, Kontopantelis E, Takkenberg JJM, Beyersdorf F. Statistical primer: checking model assumptions with regression diagnostics. Interactive CardioVascular and Thoracic Surgery. 2018;28(1):1-8. doi: 10.1093/icvts/ivy207.

19. Li G, Taljaard M, Van den Heuvel ER, Levine MA, Cook DJ, Wells GA, et al. An introduction to multiplicity issues in clinical trials: the what, why, when and how. International Journal of Epidemiology. 2016;46(2):746-55. doi: 10.1093/ije/dyw320.

20. Steinberg BA, Hellkamp AS, Lokhnygina Y, Patel MR, Breithardt G, Hankey GJ, et al. Higher risk of death and stroke in patients with persistent vs. paroxysmal atrial fibrillation: results from the ROCKET-AF Trial. Eur Heart J. 2015;36(5):288-96. Epub 2014/09/12. doi: 10.1093/eurheartj/ehu359. PubMed PMID: 25209598; PubMed Central PMCID: PMCPMC4313363.

21. Senoo K, Lip GY, Lane DA, Buller HR, Kotecha D. Residual risk of stroke and death in anticoagulated patients according to the type of atrial fibrillation: AMADEUS Trial. Stroke. 2015;46(9):2523-8. Epub 2015/07/25. doi:

\subsection{1/STROKEAHA.115.009487. PubMed PMID: 26205373.}

22. Banerjee A, Taillandier S, Olesen JB, Lane DA, Lallemand B, Lip GYH, et al. Pattern of atrial fibrillation and risk of outcomes: The Loire Valley Atrial Fibrillation Project. International Journal of Cardiology. 2013;167(6):2682-7. doi: 10.1016/j.ijcard.2012.06.118. 
medRxiv preprint doi: https://doi.org/10.1101/2021.01.30.21250715; this version posted June 17, 2021. The copyright holder for this preprint (which was not certified by peer review) is the author/funder, who has granted medRxiv a license to display the preprint in perpetuity.

It is made available under a CC-BY-NC-ND 4.0 International license .

23. Atar D, Berge E, Le Heuzey JY, Virdone S, Camm AJ, Steffel J, et al. The association between patterns of atrial fibrillation, anticoagulation, and cardiovascular events. Europace. 2020;22(2):195-204. Epub 2019/11/21. doi:

10.1093/europace/euz292. PubMed PMID: 31747004; PubMed Central PMCID: PMCPMC7005596.

24. Krittayaphong R, Chantrarat T, Rojjarekampai R, Jittham P, Sairat P, Lip GYH. Poor Time in Therapeutic Range Control is Associated with Adverse Clinical Outcomes in Patients with Non-Valvular Atrial Fibrillation: A Report from the Nationwide COOLAF Registry. J Clin Med. 2020;9(6). Epub 2020/06/06. doi: 10.3390/jcm9061698. PubMed PMID: 32498302; PubMed Central PMCID: PMCPMC735546

25. Haas S, Ten Cate H, Accetta G, Angchaisuksiri P, Bassand J-P, Camm AJ, et al. Quality of Vitamin K Antagonist Control and 1-Year Outcomes in Patients with Atrial Fibrillation: A Global Perspective from the GARFIELD-AF Registry. PLoS One. 2016;11(10):e0164076-e. doi: 10.1371/journal.pone.0164076. PubMed PMID: 27792741.

26. Nattel S, Guasch E, Savelieva I, Cosio FG, Valverde I, Halperin JL, et al. Early management of atrial fibrillation to prevent cardiovascular complications. European Heart Journal. 2014;35(22):1448-56. doi: 10.1093/eurheartj/ehu028.

27. Nieuwlaat R, Prins MH, Le Heuzey JY, Vardas PE, Aliot E, Santini M, et al. Prognosis, disease progression, and treatment of atrial fibrillation patients during 1 year: follow-up of the Euro Heart Survey on atrial fibrillation. Eur Heart J. 2008;29(9):1181-9. Epub 2008/04/10. doi: 10.1093/eurheartj/ehn139. PubMed PMID: 18397874. 
medRxiv preprint doi: https://doi.org/10.1101/2021.01.30.21250715; this version posted June 17, 2021. The copyright holder for this preprint (which was not certified by peer review) is the author/funder, who has granted medRxiv a license to display the preprint in perpetuity. It is made available under a CC-BY-NC-ND 4.0 International license.

28. Hori M, Matsumoto M, Tanahashi N, Momomura S, Uchiyama S, Goto S, et al. Rivaroxaban vs. warfarin in Japanese patients with atrial fibrillation - the J-ROCKET AF study. Circ J. 2012;76(9):2104-11. Epub 2012/06/06. doi: 10.1253/circj.cj-120454. PubMed PMID: 22664783.

29. Hori M, Connolly SJ, Zhu J, Liu LS, Lau CP, Pais P, et al. Dabigatran versus warfarin: effects on ischemic and hemorrhagic strokes and bleeding in Asians and non-Asians with atrial fibrillation. Stroke. 2013;44(7):1891-6. Epub 2013/06/08. doi: 10.1161/strokeaha.113.000990. PubMed PMID: 23743976.

30. Jachno K, Heritier S, Wolfe R. Are non-constant rates and non-proportional treatment effects accounted for in the design and analysis of randomised controlled trials? A review of current practice. BMC Med Res Methodol. 2019;19(1):103. Epub 2019/05/18. doi: 10.1186/s12874-019-0749-1. PubMed PMID: 31096924; PubMed Central PMCID: PMCPMC6524252. 


\section{Footnotes}

\section{Competing Interests: None}

\section{Contributorship}

SA and RK had the idea for and designed the study and were responsible for the overall content as guarantors. All authors collected the data. SA performed the statistical analysis. SA mainly wrote the manuscript with support from SK, PC, and RK. All authors provided critical feedback and contributed to the final manuscript.

\section{Acknowledgement: None}

\section{Sources of Funding}

This study was funded by grants from the Health Systems Research Institute (HSRI; grant no. 59-053), the Heart Association of Thailand under the Royal Patronage of H.M. the King, and the Royal College of Physicians of Thailand.

\section{Data sharing statement}

The individual anonymized data supporting the analyses contained in the manuscript will be made available upon reasonable written request.

\section{Patient and public involvement}

Patients or the public were not involved in the design, or conduct, or reporting, or dissemination plans of our research.

Patient consent for publication: Not required.

\section{Ethics approval}

The protocol for this study was approved by the institutional review boards (IRBs) of the Thailand Ministry of Public Health (which covers IRBs for Buddhachinaraj Hospital, Chiangrai 
medRxiv preprint doi: https://doi.org/10.1101/2021.01.30.21250715; this version posted June 17, 2021. The copyright holder for this preprint (which was not certified by peer review) is the author/funder, who has granted medRxiv a license to display the preprint in perpetuity.

It is made available under a CC-BY-NC-ND 4.0 International license.

Prachanukroh Hospital, Chonburi Hospital, Lampang Hospital, Maharat Nakorn Ratchasima

Hospital, Nakornping Hospital, Prapokklao Hospital (Chanthaburi), Ratchaburi Hospital, Surat

Thani Hospital, Surin Hospital, Udonthani Hospital, and Sapphasitthiprasong Hospital) and

Central Research Ethics Committee (CREC, which covers IRBs for Central Chest Institute of

Thailand, Charoen Krung Pracha Rak Hospital, Chiang Mai Hospital, King Chulalongkorn

Memorial Hospital, Naresuan University Hospital, Songklanakarind Hospital, Ramathibodi

Hospital, Siriraj Hospital, Thammasat Hospital, Golden Jubilee Medical Center, Srinakarind

Hospital, Phramongkutklao Hospital, Police General Hospital, and Faculty of Medicine Vajira

Hospital) and IRB of Queen Savang Vadhana Memorial Hospital. All patients provided written informed consent prior to participation. 
medRxiv preprint doi: https://doi.org/10.1101/2021.01.30.21250715; this version posted June 17, 2021. The copyright holder for this preprint (which was not certified by peer review) is the author/funder, who has granted medRxiv a license to display the preprint in perpetuity.

It is made available under a CC-BY-NC-ND 4.0 International license .

\section{Tables}

Table 1. Baseline Characteristics by Patterns of Atrial Fibrillation

\section{Demographics}

$\begin{array}{llll}\text { Px } & \text { Ps } & \text { Pm } & \text { Pair-wise } P \text { value }\end{array}$

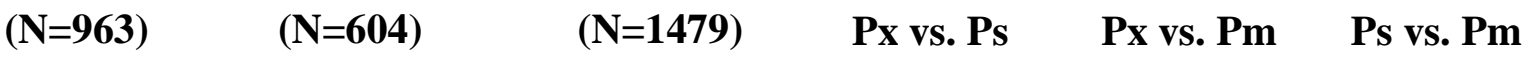

\begin{tabular}{lllllrr} 
Age, mean (SD), y & $65.9(11.3)$ & $66.8(11.1)$ & $68.1(11.0)$ & .105 & $<.001$ & .019 \\
\hline Female, No. (\%) & $461(47.9 \%)$ & $221(36.6 \%)$ & $578(39.1 \%)$ & $<.001$ & $<.001$ & .862 \\
\hline BMI, mean (SD), & $25.2(4.7)$ & $25.5(4.7)$ & $25.1(4.8)$ & .297 & .654 & .132 \\
$\mathrm{~m}^{2} / \mathrm{kg}$ & & & & &
\end{tabular}

\section{Medical History}

Current Smoker, No.

$(\%)$

$20(2.1 \%) \quad 20(3.3 \%)$

$58(3.9 \%)$

.132

.011

.506

Alcohol Use, No. (\%)

$31(3.2 \%)$

$26(4.3 \%)$

$71(4.8 \%)$

.264

.056

.626

Hypertension, No. (\%)

$642(66.7 \%)$

$409(67.7 \%)$

$1032(69.8 \%) \quad .667$

.106

.355

Diabetes, No. (\%)

$242(25.1 \%)$

$147(24.3 \%)$

$368(24.9 \%)$

.724

.890

.794

CAD, No. (\%)

$162(16.8 \%)$

$116(19.2 \%)$

$202(13.7 \%)$

.229

.032

.001 
medRxiv preprint doi: https://doi.org/10.1101/2021.01.30.21250715; this version posted June 17, 2021. The copyright holder for this preprint (which was not certified by peer review) is the author/funder, who has granted medRxiv a license to display the preprint in perpetuity.

It is made available under a CC-BY-NC-ND 4.0 International license .

Stroke/TIA, No. (\%)

$141(14.6 \%) \quad 94(15.6 \%)$

$284(19.2 \%)$

.619

.004

.051

Vascular Disease, No.

$\begin{array}{llllll}168(17.4 \%) & 125(20.7 \%) & 215(14.5 \%) & .108 & .053 & .001\end{array}$

$(\%)$

CHF, No. (\%)

$154(15.9 \%) \quad 172(28.5 \%)$

$404(27.3 \%)$

$<.001$

$<.001$

.591

Abnormal Renal

Function, N (\%)

$30(3.1 \%)$

$21(3.5 \%)$

$44(3.0 \%)$

.695

.843

.550

Abnormal Liver

Function, No. (\%)

$22(2.3 \%) \quad 16(2.6 \%)$

$33(2.2 \%)$

.648

.931

.568

Dementia, No. (\%)

$6(0.6 \%)$

$4(0.7 \%)$

$14(0.9 \%)$

.924

.386

.525

Bleeding History, No.

$(\%)$

$88(9.1 \%) \quad 52(8.6 \%)$

$159(10.8 \%) \quad .721$

.197

.142

\section{Medications}

\begin{tabular}{lllllll} 
Antiplatelet, No. (\%) & $289(30.0 \%)$ & $188(31.1 \%)$ & $332(22.4 \%)$ & .640 & $<.001$ & $<.001$ \\
\hline OAC, No. (\%) & $646(67.1 \%)$ & $448(74.2 \%)$ & $1192(80.6 \%)$ & .003 & $<.001$ & .001 \\
- VKA, No. (\%) & $557(57.8 \%)$ & $415(68.7 \%)$ & $1131(76.5 \%)$ & .007 & $<.001$ & .182 \\
- DOACs, No. (\%) & $89(9.2 \%)$ & $33(5.5 \%)$ & $61(4.1 \%)$ & .007 & $<.001$ & .182 \\
\hline Antiplatelet and OAC, & $101(10.5 \%)$ & $70(11.6 \%)$ & $104(7.0 \%)$ & .885 & $<.001$ & $<.001$
\end{tabular}


medRxiv preprint doi: https://doi.org/10.1101/2021.01.30.21250715; this version posted June 17, 2021. The copyright holder for this preprint (which was not certified by peer review) is the author/funder, who has granted medRxiv a license to display the preprint in perpetuity.

It is made available under a CC-BY-NC-ND 4.0 International license .

No. $(\%)$

\section{Risk Scores}

$\mathrm{CHA}_{2} \mathrm{DS}_{2}-\mathrm{VAS}_{\mathrm{c}}$, mean

(SD)

$\begin{array}{lllll}2.82 & \pm 1.7 & 2.95 \pm 1.6 & 3.08 \pm 1.6 & .119\end{array}$

$<.001$

.042

Stroke Risk ${ }^{*}$, No. (\%)

- Low

$142(14.7 \%) \quad 48(7.9 \%)$

$94(6.7 \%)$

$<.001$

$<.001$

.191

- Intermediate

$168(17.4 \%) \quad 116(19.2 \%)$

$139(16.2 \%)$

.379

.405

.093

- High

$653(67.8 \%) \quad 440(72.8 \%)$

$1146(77.5 \%) \quad .035$

$<.001$

.024

Abbreviations: BMI, body mass index; CAD, coronary artery disease; CHF, congestive heart failure;

DOAC, direct oral anticoagulant; OAC, oral anticoagulant; Px, paroxysmal atrial fibrillation; Ps, persistent atrial fibrillation; Pm, permanent atrial fibrillation; SD, standard deviation; VKA, vitamin K antagonist.

*Stroke risks were categorized as low $\left(\mathrm{CHA}_{2} \mathrm{DS}_{2}-\mathrm{VAS}_{\mathrm{c}}\right.$ score $=0$ in males, or 1 in female $)$, intermediate $\left(\mathrm{CHA}_{2} \mathrm{DS}_{2}-\mathrm{VAS}_{\mathrm{c}}\right.$ score of 1 in males or 2 in females $)$, and high $\left(\mathrm{CHA}_{2} \mathrm{DS}_{2}-\mathrm{VAS}_{\mathrm{c}}\right.$ score $\geq 2$ in males or $\geq 3$ in females).

Table 2. Causes of Death by Pattern of Atrial Fibrillation

Causes of Death

Paroxysmal AF Persistent AF

Permanent AF

Total Deaths

$(\mathrm{N}=56)$

$(\mathrm{N}=59)$

$(\mathrm{N}=125)$

$(\mathrm{N}=\mathbf{2 4 0})$

CV Death

$19(33.9 \%)$

$21(35.6 \%)$

$42(33.6 \%)$

$82(34.2 \%)$ 
medRxiv preprint doi: https://doi.org/10.1101/2021.01.30.21250715; this version posted June 17, 2021. The copyright holder for this preprint (which was not certified by peer review) is the author/funder, who has granted medRxiv a license to display the preprint in perpetuity.

It is made available under a CC-BY-NC-ND 4.0 International license .

Heart Failure

8

3

9

Sudden Cardiac Death

2

4

7

13

Myocardial Infarction

1

4

4

9

Intracerebral Hemorrhage

6

3

13

22

Stroke

1

4

9

14

Other CV Deaths

1

3

0

4

Non-CV Death

$26(46.4 \%)$

$26(44.1 \%)$

$58(46.4 \%)$

$110(45.8 \%)$

Infection/Sepsis

16

15

30

61

Malignancy

2

3

8

13

Pulmonary

2

2

2

6

Trauma

1

0

3

4

Hemorrhage with neither

CV bleeding or stroke

12

6

9

Other non-CV deaths

4

4

9

17

\section{Undetermined}

$11(19.6 \%)$

$12(20.3 \%)$

$25(20 \%)$

$48(20 \%)$

Abbreviations: AF, atrial fibrillation; $\mathrm{CV}$, cardiovascular. 
medRxiv preprint doi: https://doi.org/10.1101/2021.01.30.21250715; this version posted June 17, 2021. The copyright holder for this preprint (which was not certified by peer review) is the author/funder, who has granted medRxiv a license to display the preprint in perpetuity.

It is made available under a CC-BY-NC-ND 4.0 International license.

Table 3. Clinical Outcomes by Pattern of Atrial Fibrillation

Incidence (per 100

patient-years)

Px vs. Ps

Px vs. Pm

Ps vs. Pm

$\begin{array}{llllllllll}\text { All } & \text { Px } & \text { Ps } & \text { Pm } & \text { HR }^{*}(95 \% \text { CI }) & P & \text { HR }^{*}(95 \% \text { CI }) & P & \text { HR }^{*}(95 \% \text { CI }) & P\end{array}$

All-cause

0.66

0.71

1.07

$\begin{array}{llll}3.6 & 2.5 & 4.4 & 4.1\end{array}$

.029

.036

.655

Mortality

(0.46-0.96)

(0.52-0.98)

(0.78-1.47)

$\begin{array}{lll}0.62 & 0.70 & 1.12\end{array}$

CV Death $\quad 1.2 \quad 0.9 \quad 1.6 \quad 1.4$

.143

.204

.684

(0.33-1.17)

(0.4-1.26)

(0.65-1.91)

Non-CV

0.66

0.68

1.03

$\begin{array}{llll}1.7 & 1.2 & 1.9 & 1.9\end{array}$

.136

.110

.895

Death

$(0.38-1.14)$

(0.42-1.09)

(0.64-1.66) 


\section{Incidence (per 100}

patient-years)
Px vs. Ps
Px vs. Pm
Ps vs. Pm

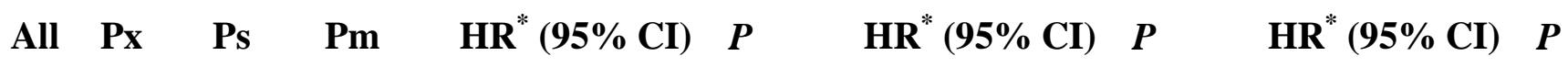

Ischemic

0.72

0.73

1.01

$\begin{array}{lllll}1.3 & 1.0 & 1.5 & 1.4 & .286\end{array}$

.235

.956

Stroke

$(0.39-1.32)$

$(0.43-1.23)$

$(0.59-1.74)$

Major

0.59

0.71

1.20

Bleeding

$\begin{array}{llll}2.1 & 1.5 & 2.6 & 2.4\end{array}$

.037

.122

Intracranial

1.21

0.92

0.76

\section{$\begin{array}{llll}0.7 & 0.6 & 0.5 & 0.8\end{array}$}

.679

.813

Hemorrhage

(0.49-3.03)

(0.47-1.79)

(0.33-1.77)

Abbreviations: CV, cardiovascular; HR, hazard ratio; Px, paroxysmal atrial fibrillation; Ps, persistent atrial fibrillation; Pm, permanent atrial fibrillation.

*HR adjusted for age, sex, body mass index, smoking status, alcohol use, hypertension, dyslipidemia, bleeding history congestive heart failure, diabetes mellitus, stroke or transient ischemic attack, vascular disease, abnormal renal function, abnormal liver function, use of antiplatelet agent, and use of anticoagulation agents. 
medRxiv preprint doi: https://doi.org/10.1101/2021.01.30.21250715; this version posted June 17, 2021. The copyright holder for this preprint (which was not certified by peer review) is the author/funder, who has granted medRxiv a license to display the preprint in perpetuity.

It is made available under a CC-BY-NC-ND 4.0 International license .

\section{Figure Legends}

Figure 1. Anticoagulation Rate by Stroke Risk and Pattern of Atrial Fibrillation. Stroke risks were categorized as low $\left(\mathrm{CHA}_{2} \mathrm{DS}_{2}-\mathrm{VAS}_{\mathrm{c}}\right.$ score $=0$ in males, or 1 in female), intermediate $\left(\mathrm{CHA}_{2} \mathrm{DS}_{2}-\mathrm{VAS}_{\mathrm{c}}\right.$ score of 1 in males or 2 in females $)$, and high $\left(\mathrm{CHA}_{2} \mathrm{DS}_{2^{-}}\right.$ $\mathrm{VAS}_{\mathrm{c}}$ score $\geq 2$ in males or $\geq 3$ in females).

Figure 2. Kaplan-Meier Cumulative Probability Curve of All-cause Mortality by Pattern of Atrial Fibrillation

Figure 3. Kaplan-Meier Cumulative Probability Curve of Ischemic Stroke by Pattern of Atrial Fibrillation 
medRxiv preprint doi: https://doi.org/10.1101/2021.01.30.21250715; this version posted June 17, 2021. The copyright holder for this preprint (which was not certified by peer review) is the author/funder, who has granted medRxiv a license to display the preprint in perpetuity.

It is made available under a CC-BY-NC-ND 4.0 International license. 
Anticoagulation Rate by Stroke Risk and Pattern of Atrial Fibrillation ( $\mathrm{N}=3046)$

$100 \%$

\section{- All -Paroxysmal $\square$ Persistent Permanent}

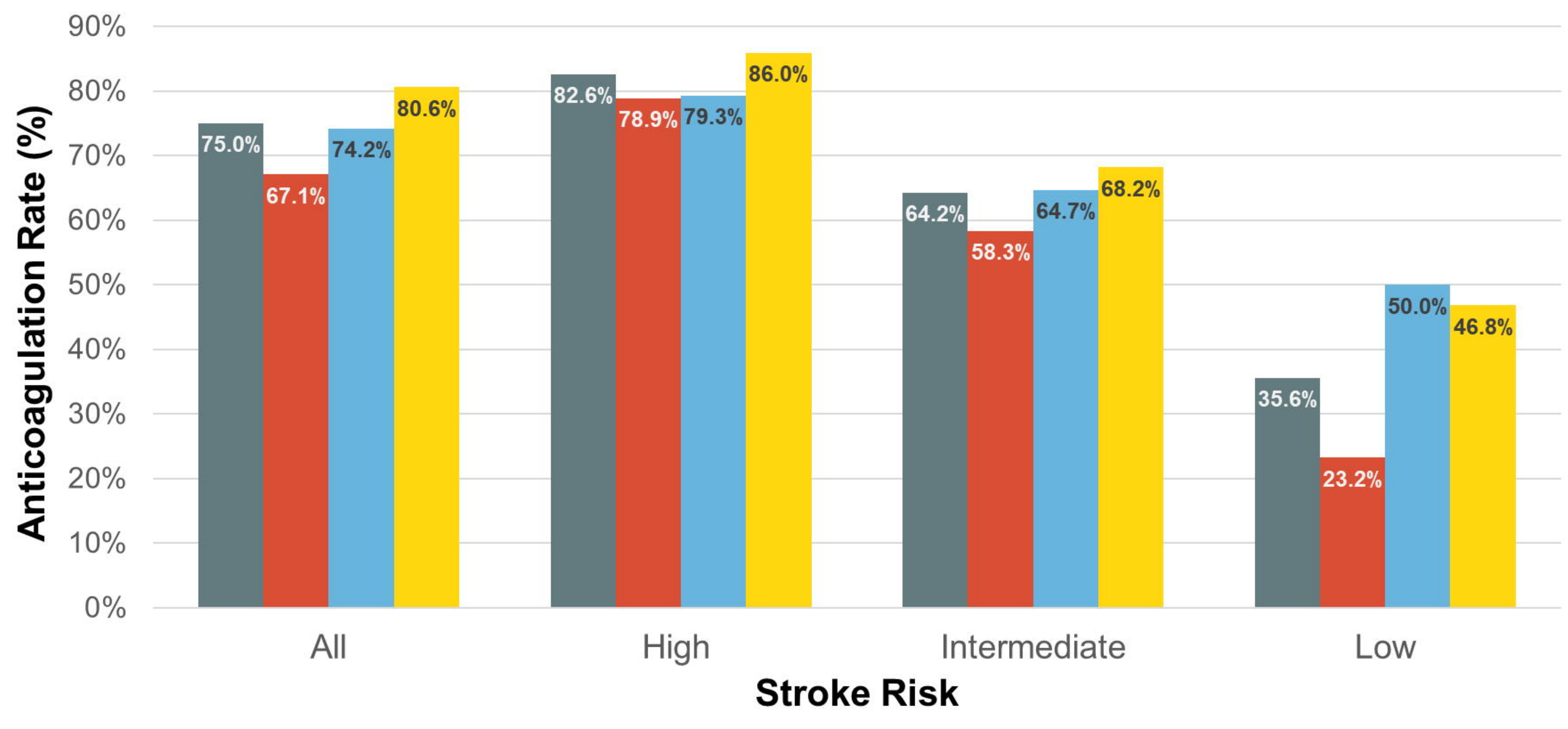




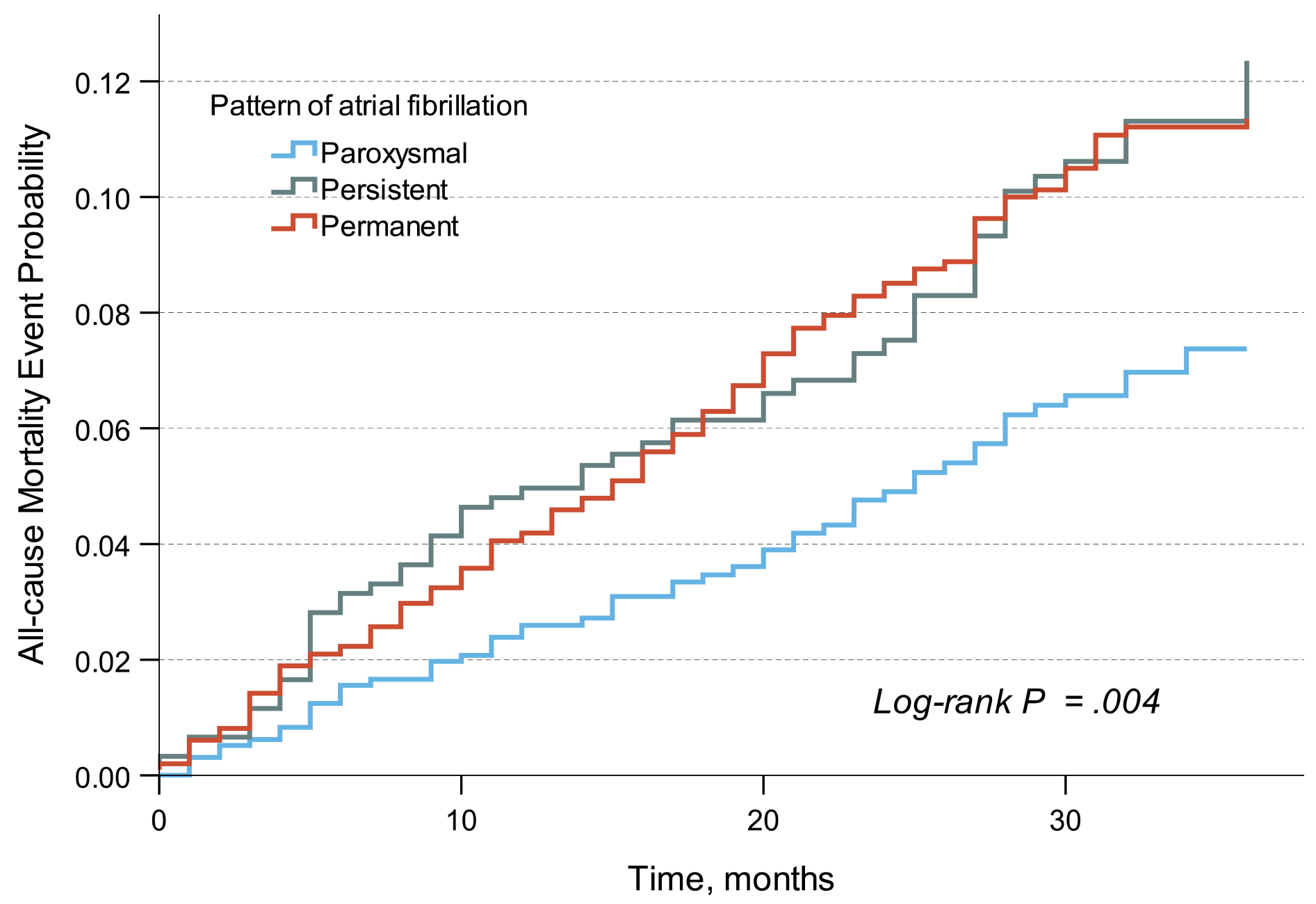




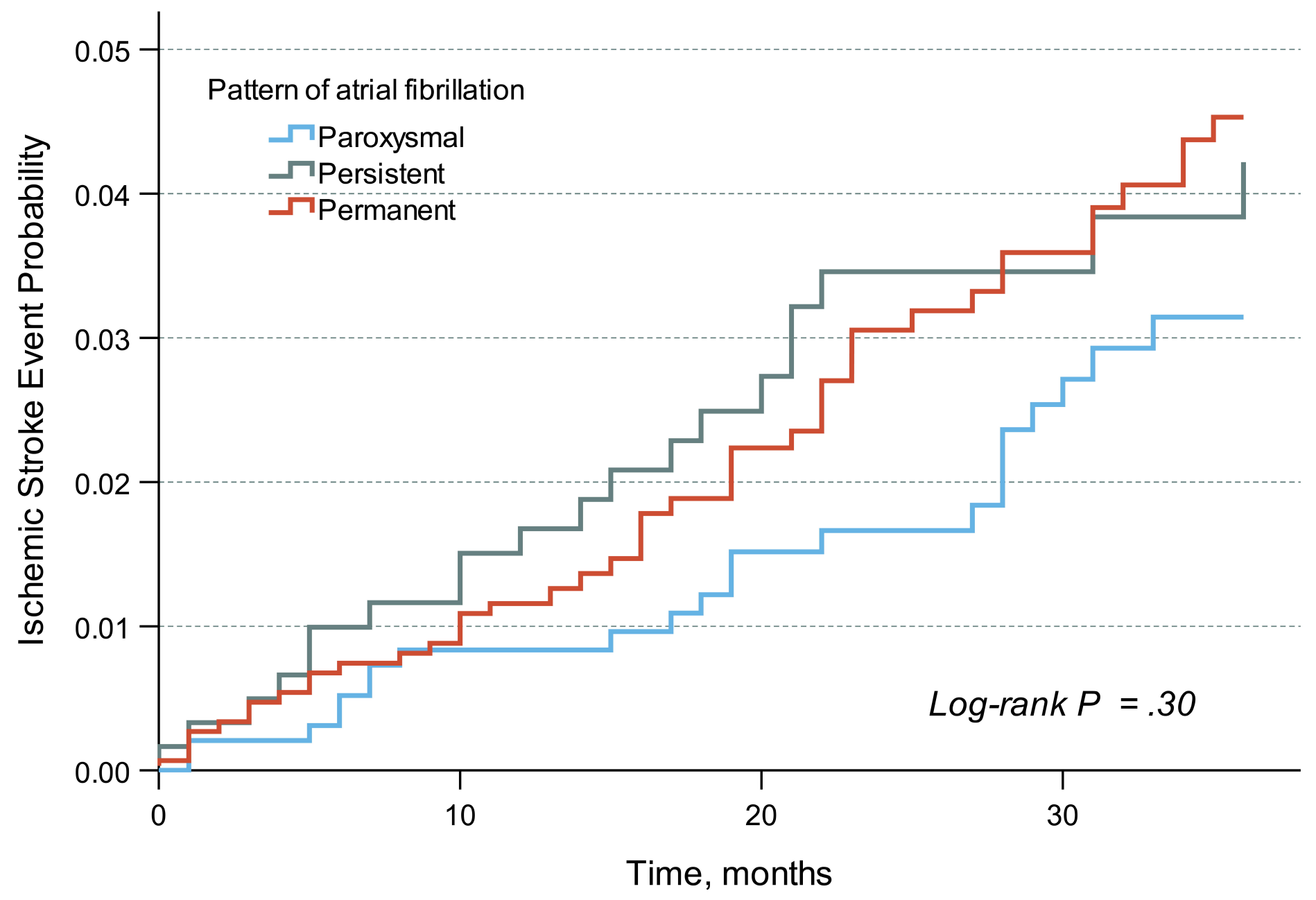

